\title{
AIKUISTEN AVAINTAITOJEN KANSAINVÄLINEN ARVIOINTI - MONITAHOINEN JA JÄNNITTEINEN
}

\author{
"Osaamista ei tulisi arvioida vain taloudellisen tai sivistyksellisen pää- \\ oman tuottajana, vaan myös sosiaalisen oikeudenmukaisuuden ja yksilöi- \\ den elämänlaadun näkökulmasta. Monet kansainväliset arvioinnit ovat jo \\ osoittaneet, että niiden kansakuntien, jotka huolehtivat parhaiten \\ heikoimmasta väestönosastaan, kehittyminen on ollut kestävintä niin \\ sivistyksellisesti kuin taloudellisestikin.”
}

\section{PIRJO LINNAKYLÄ}

"Our economy, society, and culture are built on interests, values, institutions, and systems of representations that, by and large, limit collective creativity, confiscate the harvest of information technology, and deviate our energy into self-destructive confrontation. This state of affairs must not be. There is no eternal evil in human nature. There is nothing that cannot be changed by conscious, purposive social action, provided with information, and supported by legitimacy." (Manuel Castells 1998, 379-380)

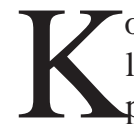

oulutuksen arviointi tähtää koulutuspolitiikan ja -järjestelmän, opetuksen ja opvan ja ajantasaisen tiedon varassa. Arviointitiedon tarve on viime vuosina kasvanut yhteiskunnan, työelämän ja kulttuurin nopean muutoksen myötä. Myös entistä avoimempi koulutuspolitiikka, päätösvallan hajauttaminen, tulosohjaus, julkisten menojen leikkaukset, koulutusrakenteiden monimuotoistuminen, opiskelijoiden itseohjautuvuus sekä pedagogisten ratkaisujen valinnaisuus ovat lisänneet tarvetta osaamisen arviointiin.

Vaikka koulutusta vaaditaan uudistettavaksi kansallisen kilpailukyvyn vahvistamiseksi, suomalainen ja laajemminkin pohjoismainen koulutuspolitiikka nojaa yhä siihen näkemykseen, että mitä tasa-arvoisempaa koulutus on, sitä varmemmin se takaa koko kansan sivistyksen sekä sosiaalisen ja taloudellisen menestyksen. Niinpä ar- viointiin liittyy parhaimmillaan vastuullisuus, yhteisesti sovittu arvoperusta ja monia metodologisia ja eettisiä vaatimuksia, joiden varassa arviointitietoa hankitaan, tulkitaan ja hyödynnetään (House, 1993; 1997).

Niin yksilöiden kuin kansakuntienkien kulttuurinen, taloudellinen ja sosiaalinen vahvuus perustuu kansalaisten osaamiseen. Millaista on aikuisten osaaminen? Miten tie-

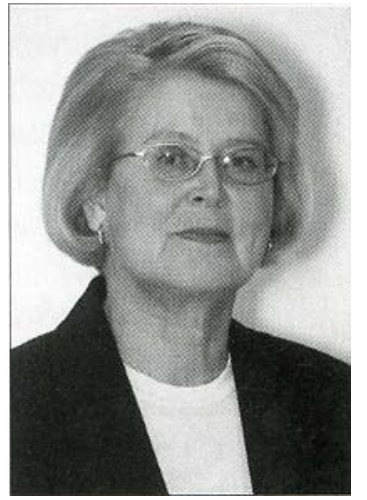

Pirjo Linnakylä dot, taidot ja asenteet vastaavat sekä yksilöiden hyvän elämän että yhteisöjen ja kansakuntien menestyksen vaatimuksia? Onko peruskoulutus ja myöhempi aikuiskoulutus tuottanut osaamista, jota yksilöt tarvitsevat arkielämässään, vapaa-aikanaan ja työssä? Vai ovatko joidenkin aikuisryhmien taidot niin perinteisiä, etteivät ne riitä tietoyhteiskunnan työtehtävien, teknologian tukemien palvelujen ja kansainvälistyvän arkikulttuurin muutokseen? Nämä kysymykset nousevat jatkuvasti esille, kun puhutaan aikuiskoulutuksen kehittämisestä.

Tieto suoritetusta tutkinnosta tai aikuiskoulutusaktiviisuudesta ei enää riitä, sillä tutkinnot vanhentuvat eivätkä takaa nyky-yhteiskunnan osaamisvaatimuksia. Aikuiskoulutusaktiivisuuskaan ei varmista aina niiden avaintaitojen hallintaa, joiden varassa voidaan hankkia uusia tietoja 
ja taitoja tai ratkaista ongelmia työssä ja sen ulkopuolellakin. Arviointitiedon tarve aikuisten osaamisesta on johtanut niin EU:n komission, OECD:n kuin UNESCOnkin suunnittelemaan aikuisten avaintaitojen uusia kansainvälisiä arviointeja tietoyhteiskunnan osaamisvaatimusten näkökulmasta.

Aikuisten osaamisen arvioinnin tarve on vahvistunut talouden globalisaation, tieto- ja viestintäteknologian kehityksen ja näihin liittyen työorganisaatioiden ja -tehtävien muutoksen sekä kulttuurin ja koulutuksen kansainvälistymisen myötä (vrt. Tynjälä, 2003). Tietoyhteiskunnassa osaamisesta ja opiskelun taidoista on tullut keskeisin yksilöiden, yhteisöjen ja kansakuntien voimavara ja kilpailukeino. Osaamisen jatkuvan kehittämisen motiivit vaihtelevat tarkastelijan mukaan. Yksilö näkee oppimisen oman potentiaalinsa vahvistamisena ja uralla etenemisenä, työnantaja taas yrityksen menestyksen, tuottavuuden ja kilpailukyvyn kannalta (Collin, 2005).

Talouden globalisoutumiseen ja koulutuksen kansainvälistymiseen liittyy tietysti myös uhkatekijöitä mm. taloudellisen kilpailun koveneminen, alueiden eriarvoistuminen sekä kansakuntien ja yksilöiden jakautuminen menestyjiin ja syrjäytyviin. Osaamista ei tulisikaan arvioida vain taloudellisen tai sivistyksellisen pääoman tuottajana, vaan myös sosiaalisen oikeudenmukaisuuden ja yksilöiden elämänlaadun näkökulmasta. Monet kansainväliset arvioinnit ovat jo osoittaneet, että ne kansakunnat, jotka huolehtivat parhaiten heikoimmasta väestönosastaan, kehittyvät kestävimmin niin sivistyksellisesti kuin taloudellisestikin (OECD, 2000; 2001).

Koulutusjärjestelmän arviointi ja kehittäminen ei kuitenkaan enää onnistu yksin kansallisesti, sillä Euroopan ja maailman yhdentyessä koulutuksen, opetuksen ja oppimisen ongelmat ovat paljolti yhteisiä, ja niitä on myös yhdessä ratkaistava sekä seurattava ratkaisujen toimivuutta ja tuloksellisuutta kansallisen koulutusjärjestelmän ja opetuskulttuurin kehittämiseksi.

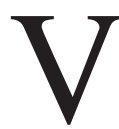
äestön ikääntyminen ja syntyvyyden väheneminen Euroopassa merkitsevät väestön ikärakenteen muutosta. Miten ikääntyvän väestön osaaminen riittää tietoyhteiskunnan työtehtävissä, jotka muuttuvat monta kertaa pitkittyvällä työuralla? Tietoteknologian lisääntyminen sekä työtehtävissä että yhteiskunnan palvelujen hyödyntämisessä asettaa myös uusia osaamisvaatimuksia, joihin kouluttaminen on ollut mahdotonta vuosikymmeniä sitten. Kun työura pitenee, ikääntyvät työntekijät tarvitsevat uusia taitoja, joista osa on yleisiä, osa hyvinkin spesifejä tehtäviin ja tilanteeseen sidottuja. Koulutusjärjestelmää kehitettäessä tarvitaan arviointitietoa siitä, mikä on ikääntyvien työntekijöiden osaamisen taso, missä on heidän vahvuutensa ja missä koulutusta vielä tarvitaan.

Erityisesti arviointitietoa tarvitaan jo nyt työelämän ulkopuolelle jääneiden ja työtä etsivien osaamisesta. Miksi työtä ei löydy, vaikka muodollista koulutusta ja etenkin työvoimakoulutusta saattaa olla jo runsaasti? Mitkä ovat ne avaintaidot, jotka työnhakijalta puuttuvat ja joiden varassa uutta osaamista ja elämänhallintaa on mahdollista rakentaa? Ovatko ne sellaisia taitoja, joita voi oppia koulutuksessa, vai sellaisia, joita omaksutaan työssä? Työttömien joukossa on myös maahanmuuttajia, joiden osaamisen tasosta ja ongelmista tarvitaan lisätietoa. Monet ovat hyvin koulutettuja, mutta eivät silti saa työtä. Missä ovat työllistymisen ongelmat? Ovatko ne tietoyhteiskunnan kannalta vääränlaisessa osaamisessa vai onko ongelma pikemminkin työnantajien, jotka eivät usko maahanmuuttajien osaamisen tasoon.

Uudet työtehtävät teknologioineen tuottavat myös uudenlaista työssä oppimista, joka perustuu vahvasti aiempaan sekä teoreettiseen että käytännölliseen osaamiseen. Monesti jo työtehtävät itsessään sisältävät opiskelua ja työkäytännöt ovat yhteisöllisesti jaettuja ja sitä kautta opittuja, verkottuneita ja kontekstisidonnaisia (Collin, 2005).

Työssä saavutettua osaamista on vaikea kuvata formaalin koulutuksen tutkinnoilla tai kurssisuorituksilla. Etenkin työssä opittua prosessuaalista tietoa, suunnittelun ja toteutuksen taitoja, viestinnällisiä ja sosiaalisia taitoja, jotka työkontekstissa toimivat ammatilliseen tietoon yhdistyneinä, on vaikea osoittaa (Collin, 2005). Näitä taitoja ei useinkaan muodollisen opiskelun yhteydessä arvioida eikä niiden osaamista näy ansioluettelosta. Ne saattavat silti olla uusissa työtehtävissä keskeisiä. Tällaisen usein hiljaisen, näkymättömän ja äänettömän osaamisen näkyväksi tekeminen voi olla arvioinnin yhtenä tavoitteena, joka välillisesti tukee aikuiskoulutuksen kehittämistä vastaamaan entistä osuvammin todellisten työtehtävien vaatimuksia. 
KESKEISIMMÄT

\section{ARVIOINTIHAASTEET}

Aikuisten osaamista arvioitaessa huomio pyritään kiinnittämään sekä koulutus- että työvoimapoliittisesti keskeisiin kysymyksiin. Esimerkiksi OECD:n koordinoimassa Aikuisten avaintaitojen arvioinnissa (Programme for International Assessment of Adult Competencies, PIAAC), jota parhaillaan valmistellaan ja joka on tarkoitus toteuttaa vuosina 2008-2010, huomio kohdistetaan erityisesti seuraaviin kaikissa OECD:n jäsenmaissa koulutus- ja työvoimapoliittisesti keskeisiin kysymyksiin (OECD, 2004):

। Mitkä ovat tietoyhteiskunnan työtehtävien osaamisvaatimukset ja miten aikuisten avaintaidot näitä vastaavat? Miten samanlaisia vaatimukset ja avaintaidot ovat eri maissa ja väestöryhmissä: eri-ikäisillä, eri sukupuolilla, eri konteksteissa, eri ammateissa ja maahanmuuttajaryhmissä? Miten tasa-arvoiset ovat opiskelumahdollisuudet?

। Millaiset koulutusratkaisut tuottavat sellaista osaamista, jota aikuiset itse ja työelämä arvostaa ja joka luo perustaa uusien tietojen ja taitojen oppimiselle? Mitkä koulutusratkaisut edistävät osaamista, joka tukee tasa-arvon toteutumista jatkokoulutuksessa, perheessä ja työelämässä sekä ikääntyvien mutta myös nuorten, maahanmuuttajien ja pitkäaikaistyöttömien työllistymisessä?

। Miten avaintaitojen hallinta tukee työllistymistä ja työpaikan vaihtamista? Miten hallinta liittyy sosiaalisiin suhteisiin, terveydentilaan ja yhteiskunnalliseen aktiivisuuteen? Miten hyvin osaamista hyödynnetään työtehtävissä? Onko olemassa yli- tai väärinkouluttautumisen mahdollisuus?

I Miten avaintaitojen hallinta indikoi inhimillisen pääoman kasvua ja miten tämä näkyy yksilöiden elämänpolitiikassa ja tulotasossa, miten kansantaloudessa ja yhteiskunnan sosiaalisessa koheesiossa?

Edellä kuvattuista arviointitehtävistä on neuvoteltu OECD:n jäsenmaiden asiantuntijaryhmässä vuoden 2004-2005 aikana. Kaikkiin esitettyihin kysymyksiin ei yhdellä arvioinnilla saada vastauksia, mutta aikuisten avaintaitojen arviointi on tarkoitus toteuttaa PISA-ohjelman tavoin useana syklinä, jolloin huomio voidaan kohdentaa eri kerroilla eri teemoihin ja vielä niin, että ensimmäi- sellä kerralla saadut tulokset, esimerkiksi työelämän taitovaatimuksista, voidaan seuraavalla kerralla ottaa huomioon avaintaitojen määrittelyssä ja arviointimenetelmien validoinnissa.

\section{MITÄ ETUA KANSAINVÄLISESTÄ ARVIOINNISTA?}

Parhaimmillaan kansainvälinen arviointitoiminta täydentää kansallista. Kansainväliset arvioinnit tarjoavat yhtä koulutusjärjestelmää laajemman kehyksen tarkastella myös kansallista koulutuspolitiikkaa ja käytännön ratkaisuja sekä näiden tuottamia tuloksia. Kansainvälisesti koulutusratkaisujen variaatio on suurempi kuin kansallisesti, millä voi ratkaiseva merkitys, kun suunnitellaan uutta koulutuspolittiikkaa ja vaihtoehtoisia koulutusmalleja. Kun tarkastellaan eri maiden aikuisten osaamista ja sen jakautumista eri väestöryhmissä ja suhteutetaan näitä poliittisiin, koulutuksellisiin, taloudellisiin ja sosiaalisiin ehtoihin, nähdään paremmin, missä ovat vahvuudet ja missä tärkeimmät kehittämishaasteet.

Kansainväliset vertailukohteet voidaan valita maailmanlaajuisesti tai pelkästään OECD:n tai EU:n piiristä. Tuloksia voidaan tarkastella myös pohjoismaisessa kontekstissa, joka tarjoaa arvoperustaltaan ja resursseiltaan vertailukelpoisimman kehyksen. Maamerkeiksi voidaan valita vertailumaiden keskimääräinen laatutaso, parhaiten menestyneiden taso tai oman maan aiempi suoritustaso, jos seuranta-aineisto on käytettävissä. Kiinnostava on verrata maita, joiden koulutuspolitiikka ja opetuskulttuuri muistuttavat paljon toisiaan, mutta joiden tulokset poikkevat merkittävästi. Toisaalta mielenkiintoista on tarkastella myös niiden maiden tilannetta, joissa tulokset ovat samanatasoisia, vaikka koulutusjärjestelmä on hyvinkin erilainen. Esimerkiksi Suomen, Kanadan, Uuden-Seelannin ja Etelä-Korean perusopetuksen päättövaiheen oppimistulokset ovat keskimäärin samantasoisia, vaikka osaaminen jakautuu eri tavoin, mikä taas heijastaa opetuskulttuurien ja koulutusjärjestelmien eroja.

Kansainväliset arvioinnit antavat myös mahdollisuuden tutustua tarkemmin erilaisiin koulutusjärjestelmiin ja niiden ongelmiin sekä erilaisiin tapoihin ratkaista samoja ongelmia ja arvioida erilaisten ratkaisumallien tuloksellisuutta. Kun Suomen tilannetta verrataan esimerkiksi Englantiin, jossa aikuiskoulutusjärjestelmä on pitkälle kehittynyt ja erilaisia kehittämishankkeita on huomat- 
tavasti enemmän kuin meillä (Howard, 2005), on kuitenkin huomattava, että perusopetuksen päättövaiheessa englantilaisista nuorista aikuisista suhteellisesti huomattavasti suurempi osa kuin meillä jää perustaidoiltaan heikoksi ja näin ollen tarvitsevatkin monipuolista aikuiskoulutusta syrjäytymisen ehkäisemiseksi (McNeil, 2005). Tämä herättää pohtimaan sitä, onko parempi kehittää perusopetusta ja heikkojen tukemista varhaisvaiheessa vai laajentaa toisen koulutusmahdollisuuden tarjoamista.

Kansainväliset arvioinnit syventävät ja laajentavat ymmärrystämme arviointitulosten taustalla ja niihin yhteydessä olevista tekijöistä. Kansainvälisessä kontekstissa on mahdollista laaja-alaisessa asiantuntijaverkostossa rakentaa synergiaa hyödyntäen vahvaa monitieteistä teoreettista kehystä ja selitysmalleja, joilla on paitsi kansainvälistä myös kansallista merkitystä. Samalla voidaan kasvattaa kansallista kapasiteettia aikuisten osaamisen ja siihen yhteydessä olevien tekijöiden arviointiin. Kansainväliset arvioinnit tuottavat myös laajoja empiirisiä aineistoja, joilla on jatkuvaa tutkimusmerkitystä ja jotka voivat toimia kansallisten ja kansainvälistenkin jatkotutkimusten ja syventävien analyysien pohjana (esim. Linnakylä \& Malin, 2001; 2002).

\section{AIKUISTEN AVAINTAIDOT KANSAINVÄLISEN ARVIOINNIN KOHTEENA}

Aikuisten perustaitojen hallintaa on arvioitu kansainvälisesti jo muutamassa laajassa vertailututkimuksessa. Ensimmäinen arviointi (International Adult Literacy Survey, IALS), joka toteutettiin vuosina 1994-1998, kohdistui aikuisten lukutaitoon ja aikuiskoulutukseen (OECD, 1999). Tätä arviointia koordinoi Kanadan tilastovirasto yhteistyössä OECD:n kanssa. Toinen arviointi (Adult Literacy and Lifeskills Survey, ALL) vuosina 2002-2004 on ollut sisällöllisesti edellistä laajempi ja kohdistunut lukutaidon ohella matematiikan perustaitoihin, ongelmanratkaisuun sekä tiimityön taitoihin ja tietotekniikan käyttöön. Suomi on osallistunut näistä vain ensimmäiseen vuonna 1998. Tässä arvioinnissa suomalaisten aikuisten lukutaidon taso osoittautui erinomaiseksi ja nuorimman ikäkohortin (16-25 -vuotiaiden) taidot 20 osallistujamaan parhaiksi. Vaikka parhaitten ja heikoimpien lukijoiden tasoero oli kansainvälisesti verraten pieni, nuorimman ja vanhimman
(56-65 -vuotiaiden) ikäkohortin taitotaso oli kuitenkin hyvin erilainen, jopa kansainvälisesti, vaikka koulutustaustakin vakioitiin. Myös aikuiskoulutusaktiivisuus ja etenkin omiin kiinnostuksiin liittyvä koulutus oli Suomessa huippuluokkaa. Aikuiskoulutus oli kuitenkin varsin kasautuvaa, niin että vähiten koulutetut ja heikoimmat avaintaidot omaavat olivat passiivisimpia (Linnakylä ym., 2000).

Samaa arviointikehystä ja metodologiaa, mutta kehitysmaiden tarpeisiin sovitettuna, on käytetty UNESCO:n ja Maailmanpankin yhdessä koordinoimassa LAMP-arvioinnissa kehitysmaiden yli 15-vuotiaiden nuorten ja aikuisten lukutaidon kartoittamiseksi ja näiden maiden arviointikapasiteetin vahvistamiseksi. Tämä arviointi on parhaillaan käynnissä. Lisäksi Euroopan komission tukemana ja neljän eurooppalaisen yliopiston konsortion koordinoimana on toteutettu vieraiden kielten osaamisen diagnostista arviointia DIALANG-ohjelmassa vuodesta 2003. Suomesta Jyväskylän yliopisto on ollut yhtenä koordinoijana tässä hankkeessa.

OECD käynnisti vuonna 2004 jo edellä mainitun Aikuisten avaintaitojen arviointiohjelman (PIAAC) valmistelun jäsenmaiden arviointiasiantuntijoiden yhteistyönä. Mukana suunnittelussa on ollut myös EU:n, UNESCOn sekä Euroopan ammattiliittojen edustajat. Olen toiminut Suomen edustajana asiantuntijaryhmässä. Suomi ei kuitenkaan ole vielä sitoutunut osallistumaan varsinaiseen arviointiin.

PIAACin suunnittelun yhteydessä on tullut selväksi, että aikuisten avaintaitoja on määriteltävä edellisiä hankkeita monipuolisemmin ja vastaamaan paremmin yksilöiden oman elämän, aktiivisen kansalaisuuden ja työelämän vaatimuksia (OECD, 2004).

\section{AVAINTAITOJEN ARVIOINTI- KEHYKSEN SUUNNITTELU}

Viime vuosien kansainväliset arvioinnit ovat suunnanneet katseensa koulutusrakenteista ja opetuskäytännöistä tietoyhteiskunnassa ja etenkin tulevaisuuden arkitilanteissa - opiskelussa, vapaa-ajan harrastuksissa, työssä ja yhteiskunnallisessa toiminnassa - keskeisiin avaintaitoihin. Avaintaidoilla tarkoitetaan laaja-alaisia geneerisiä taitoja, joilla on merkitystä niin yksilöiden henkisen kasvun ja uuden oppimisen, kuin kulttuurin uudistumisen ja yhteiskunnan kehityksen 


\begin{tabular}{|c|c|c|c|c|c|c|}
\hline Arvioinnit & Mitä? & Ketä? & Miten? & Kuka? & Milloin? & Miksi? \\
\hline $\begin{array}{l}\text { IALS } \\
\text { (Kanadan } \\
\text { tilastovirasto } \\
\text { \& OECD) }\end{array}$ & $\begin{array}{l}\text { Aikuisten } \\
\text { lukutaito } \\
\text { ja aikuis- } \\
\text { koulutus }\end{array}$ & $\begin{array}{l}16-65- \\
\text { vuotiaat } \\
20 \\
\text { maassa }\end{array}$ & $\begin{array}{l}\text { Lukutaidon } \\
\text { testaus ja } \\
\text { aikuiskou- } \\
\text { lutuksen } \\
\text { kartoitus }\end{array}$ & $\begin{array}{l}\text { Hallitukset } \\
\text { yhdessä } \\
\text { tilasto- } \\
\text { viraston ja } \\
\text { tutkimus- } \\
\text { laitosten } \\
\text { kanssa }\end{array}$ & 1994-98 & $\begin{array}{l}\text { Selvittää aikuisten } \\
\text { lukutaidon taso } \\
\text { aikuiskoulutuksen } \\
\text { kehittämiseksi }\end{array}$ \\
\hline $\begin{array}{l}\text { ALL } \\
\text { (Kanadan } \\
\text { tilastovirasto } \\
\text { \&OECD) }\end{array}$ & $\begin{array}{l}\text { Aikuisten } \\
\text { luku- ja } \\
\text { laskutaito, } \\
\text { ongelman- } \\
\text { ratkaisu- } \\
\text { taito ja } \\
\text { tiimityös- } \\
\text { kentely }\end{array}$ & $\begin{array}{l}16-65- \\
\text { vuotiaat } \\
7 \text { maassa }\end{array}$ & $\begin{array}{l}\text { Taitotestit } \\
\text { ja tausta- } \\
\text { tekijöiden } \\
\text { kartoitus }\end{array}$ & $\begin{array}{l}\text { Hallitukset } \\
\text { tilasto- } \\
\text { viraston ja } \\
\text { tutkimus- } \\
\text { laitosten } \\
\text { kanssa }\end{array}$ & 2002-04 & $\begin{array}{l}\text { Selvittää aikuisten } \\
\text { avaintaitojen } \\
\text { taso koulutuksen } \\
\text { kehittämiseksi }\end{array}$ \\
\hline $\begin{array}{l}\text { DIALANG } \\
\text { (Euroopan- } \\
\text { komissio) }\end{array}$ & $\begin{array}{l}\text { Vieraiden } \\
\text { kielten } \\
\text { (14 kielen) } \\
\text { osaaminen }\end{array}$ & $\begin{array}{l}\text { yli } 16- \\
\text { vuotiaat; } \\
\text { kuka } \\
\text { tahansa }\end{array}$ & $\begin{array}{l}\text { Verkko- } \\
\text { välitteinen } \\
\text { testaus } \\
\text { kielitaidon } \\
\text { viidellä } \\
\text { osa-alueella }\end{array}$ & $\begin{array}{l}\text { Kansain- } \\
\text { välinen } \\
\text { neljän } \\
\text { yliopistojen } \\
\text { konsortio }\end{array}$ & $\begin{array}{l}\text { Vuodesta } \\
2003-\end{array}$ & $\begin{array}{l}\text { Kielitaidon, } \\
\text { omatoiminen } \\
\text { diagnostiseen } \\
\text { testaus }\end{array}$ \\
\hline $\begin{array}{l}\text { LAMP } \\
\text { (UNESCO, } \\
\text { World Bank) }\end{array}$ & $\begin{array}{l}\text { Lukutaito } \\
\text { kehitys- } \\
\text { maissa }\end{array}$ & $\begin{array}{l}\text { Yli15- } \\
\text { vuotiaat } \\
\text { aikuiset }\end{array}$ & $\begin{array}{l}\text { Lukutaidon } \\
\text { testaus ja } \\
\text { koulutus- } \\
\text { kartoitus } \\
\text { (ALL-mit- } \\
\text { taristo) }\end{array}$ & $\begin{array}{l}\text { Kehitys- } \\
\text { maissa } \\
\text { pilotoitu }\end{array}$ & $\begin{array}{l}\text { Esikokeet } \\
\text { 2004-05 }\end{array}$ & $\begin{array}{l}\text { Koulutus- } \\
\text { ohjelmien } \\
\text { suunnittelemiseksi } \\
\text { ja arviointikapasi- } \\
\text { teetin kehittämi- } \\
\text { seksi }\end{array}$ \\
\hline $\begin{array}{l}\text { PIAAC } \\
\text { (OECD) } \\
\text { suunnitteilla }\end{array}$ & $\begin{array}{l}\text { Aikuisten } \\
\text { avain- } \\
\text { taidot }\end{array}$ & $\begin{array}{l}\text { 16-65- } \\
\text { vuotiaat; } \\
\text { mahdolli- } \\
\text { sesti } \\
\text { myös } \\
\text { vanhem- } \\
\text { mat }\end{array}$ & $\begin{array}{l}\text { Avaintaito- } \\
\text { jen testaus } \\
\text { ja työtehtä- } \\
\text { vien vaati- } \\
\text { mien taito- } \\
\text { jen itse- } \\
\text { arviointi, } \\
\text { koulutuk- } \\
\text { sen ja } \\
\text { tausta- } \\
\text { tekijöiden } \\
\text { kartoitus }\end{array}$ & $\begin{array}{l}\text { Hallitukset } \\
\text { tilasto- } \\
\text { viraston ja } \\
\text { tutkimus- } \\
\text { laitosten } \\
\text { kanssa }\end{array}$ & 2008-10 & $\begin{array}{l}\text { Selvittää aikuisten } \\
\text { avaintaitojen taso } \\
\text { sekä työtehtävien } \\
\text { ja aikuisten arjen } \\
\text { vaatimukset } \\
\text { koulutuksen } \\
\text { kehittämiseksi }\end{array}$ \\
\hline
\end{tabular}


kannalta. Ne eivät sitoudu tiukasti tieteenaloihin eivätkä ole pelkästään kognitiivisia taitoja, vaan niihin katsotaan kuuluvaksi myös asenteita ja arvostuksia, sosiaalisen vuorovaikutuksen erilaisia muotoja, itsetuntemusta ja -luottamusta sekä oman elämän politiikkaa, suunnittelua, valtautumista ja hallintaa (European Comission, 2004; OECD, 2004; Rychen \& Salganik, 2003; vrt. Pohjonen, 2005; Ruohotie, 2005).

Keskeisiksi avaintaidoiksi, joita jokaiselta kansalaiselta odotetaan, on useimmiten määritelty luku- ja kirjoitustaito sekä suullinen kommunikointi äidinkielellä ja jollakin vieraalla kielellä, matematiikan ja luonnontieteiden osaaminen, yhteiskunnallinen tietous ja aktiivisuus, tietotekniikan tarkoituksen- ja tilanteenmukainen käyttö, opiskelun ja oppimaan oppimisen taidot, sosiaaliset taidot sekä ryhmässä työskentelyn ja verkottumisen taidot. Myös luovuutta, innovatiivisuutta, ongelmanratkaisua, johtamista, muutoksen hallintaa ja yrittäjyyttä samoin kuin esteettisyyttä, terveystietoa ja kulttuurin arvostamista on eri yhteyksissä sisällytetty avaintaitoihin (European Comission, 2004; OECD, 2004; vrt. Kuusi, 1997; Pohjonen, 2005; Ruohotie, 2005).

Avaintaitojen määrittelyä ja arviointikehystä on kansainvälisenä ja laaja-alaisena yhteistyönä suunniteltu DeSeCo (Definition and Selection of Competencies) -hankkeessa, jota hyödynnetään myös PIAAC-arvioinnin yleisenä teoreettisena kehyksenä. DeSeCo-hanke käynnistyi vuonna 1997 sveitsiläisten tutkijoiden aloitteesta ja myöhemmin OECD:n tukemana (Rychen \& Salganik, 2001). Tavoitteena on ollut määritellä ja valikoida geneerisiä avaintaitoja, jotka ovat keskeisiä sekä yksilön omalle henkilökohtaiselle elämälle että työssä ja yhteiskunnassa menestymiselle. Lisäksi pyrittiin selvittämään sitä, miten avaintaidot liittyvät toisiinsa ja miten päteviä ne ovat eri maissa ja kulttuureissa, elämän eri vaiheissa, julkisessa ja yksityisessä kontekstissa sekä poliittisessa, taloudellisessa ja kasvatuksellisessa mielessä.

Määrittely ja valinta ei ole ollut ongelmatonta, sillä tieto- ja taitovaatimuksia voi lähestyä monesta näkökulmasta. Joidenkin tutkijoiden mielestä (esim. Goody, 2002) eri kulttuureille yhteisiä avaintaitoja ei kaiken kaikkiaan voi löytyä, sillä elämäntavat sekä tarpeelliset tiedot ja taidot liittyvät arvostuksiin, jotka poikkeavat merkittävästi eri kulttuureissa ja alakulttuureissa. Toisaalta jo yhdessä maassa näkemykset tietoyhteiskun- nan kriittisistä avaintaidoista voivat vaihdella merkittävästi. Esimerkiksi Saksassa oli 90-luvun viimeisen viiden vuoden aikana määritelty 650 erilaista avaintaitoa keskeisiksi tietoyhteiskunnan työssä ja elämässä menestymiseksi (Weinert, 2001). Myös Suomessa on avaintaitoja määritelty eri lähtökohdista, eniten kuitenkin tietoyhteiskuntakehityksen työelämävalmiuksien kannalta (esim. Ruohotie, 2005, Tynjälä, 2003; Vesterinen, 2001) ja useita kymmeniä tieto-, asenne- ja taitoalueita on meilläkin lueteltu keskeisiksi. Avaintaito - key competence - määriteltiin DeSeCo-hankkeessa lopulta "kyvyksi kohdata menestyksellisesti koulutuksen, työn, sosiaalisten tilanteiden ja yksilön omien pyrkimysten tiedolliset, taidolliset ja asenteelliset vaatimukset" (Weinert, 2001).

Keskeisimpien avaintaitojen valikointi toteutettiin DeSeCo:ssa monivaiheisena prosessina. Ensiksi koottiin eri tieteenalojen tutkijoiden asiantuntija-artikkeleita tärkeimmistä avaintaidoista. Tämän jälkeen laadittiin avaintaidon alustava määritelmä (Weinert, 2001), jota eri tieteenalojen asiantuntijat jälleen kriittisesti arvioivat. (Salganik \& Rychen, 2001). Määrittelyn pohjalta koottiin OECD:n jäsenmailta kansallisesti keskeisimpien avaintaitojen valikoima. Lisäksi pyydettiin asiantuntija-arvioita yhteiskunnan eri sektoreilta: koulutuksesta, työelämästä, terveydenhuollosta, liike-elämästä, UNESCOsta, ILOsta, OECD:stä ja Maailmanpankista. Näitten eri tahoilta saatujen näkemysten perusteella luotiin aikuisten avaintaitojen arviointikehys.

Määrittely paljasti monia jännitteitä ja ristiriitoja, jotka ovat hyvin todellisia myös yhteiskunnassa ja aikuisten arjessa. Onko keskeistä painottaa yksilön elämänlaatua vai yhteiskunnan menestystä, koulutuksen vai työelämän näkökulmaa, teoriaa vai käytäntöä, tietoja, asenteita vai laaja-alaisia taitoja, yleissivistystä vai spesifiä ammatillista osaamista? Ammatillisiakin tietoja ja taitoja voidaan tarkastella erilaisten työntekijäryhmien tai työnantajan kannalta sekä työkontekstia niin yksilön kokemana kuin työpaikkakohtaisesti, paikallisesti, kansallisesti tai globaalisti (Rychen \& Salganik, 2003). Vaarana voi olla, että talouden ja tietotyön tehtävät nähdään ensisijaisena ja että yksilön, ja etenkin yhteiskunnan heikoimpien, näkökulma unohtuu tai että sosiaalisen oikeudenmukaisuuden ja koheesion tavoite jää liian vähälle huomiolle. Toisaalta on mahdollista, että tietoyhteiskunnan työelämän todellisia 
valmiuksia ja vaatimuksia vähätellään ja avaintaidot kiinnitetään perinteiseen sivistyskäsitykseen tai oppiaineisiin tai rajataan sellaisiksi, joita on helppo arvioida tai joissa on jo luotettaviksi testattuja mittavälineitä käytössä.

Vaikka kansalliset järjestelmät ja koulutuspolitiikat eroavat toisistaan, avaintaitojen kansallisissa valikoimissa oli kuitenkin enemmän yhteistä kuin erilaista. Seuraavat avaintaidot nousivat useimmiten esille (Salganik \& Stephens, 2003):

\section{Lähes kaikissa kansallisissa avaintaitoluetel- missa esiintyivät seuraavat:}

। sosiaaliset taidot ja yhteistyökyky

laaja-alainen luku- ja kirjoitustaito

tieto- ja viestintätekniikan käyttötaito

oppimaan oppiminen ja elinikäinen oppiminen sekä oppimishalu

। kommunikointi äidinkielellä ja vierailla kielillä

\section{Useimmissa maissa mainittiin lisäksi seuraa- vat:}

1 itseluottamus ja itseohjautuvuus

yhteiskunnallinen tietous ja demokratian toimintaperiaatteet

। ekologian tuntemus ja läheinen suhde luontoon

I vastuuntunto, rehellisyys, eettiset normit (uskonto)

\section{Monissa maissa mainittiin lisäksi seuraavia:}

। terveystieto ja fyysisen kunnon vaaliminen kulttuurinen kompetenssi (luovuus, esteettisyys, monikulttuurisuus, medialukutaito)

Avaintaitojen monivaiheisen määrittelyn ja avoimen kansainvälisen keskustelun tuloksena päädyttiin seuraaviin kaikille aikuisille yhteisiin taitokokonaisuuksiin, jotka ovat keskeisiä niin yksityiselämässä, työssä kuin yhteiskunnallisessa toiminnassakin (Rychen, 2003):

। tiedollisten, sosio-kulttuuristen ja teknologisten välineiden vuorovaikutteinen käyttö

। kommunikointi sosiaalisesti ja kulttuurisesti heterogeenisissa ryhmissä

। itsenäinen ja suunnitelmallinen toiminta.

Tiedollisiksi ja sosio-kulttuurisiksi välineiksi katsotaan monipuolinen luku- ja kirjoitustaito sekä kommunikointi äidinkielellä ja vierailla kielillä. Tähän taitoalueeseen sisältyy matemaattinen ja luonnontieteellinen osaaminen sekä historian, kulttuurin ja yhteiskunnan tuntemus. Tekniset välineet voivat vaihdella perinteisestä teknologiasta uusimman tietotekniikan monipuoliseen ja vuorovaikutteiseen hyödyntämiseen. Keskeistä taitoalueelle on kuitenkin tilanteen, tarkoituksen ja arvostusten mukainen kriittinen tiedonkäyttö, johon liittyy myös kiinnostus ja halukkuus uuden oppimiseen.

Sosiaaliset taidot ja kommunikointi monikulttuurisissa ryhmissä pyrkii vahvistamaan sosiaalista koheesiota ja oikeudenmukaisuutta sekä pienissä opiskelu- ja työryhmissä että kansallisissa ja kansainvälisissä verkostoissa. Keskeisiä osataitoja ovat vuorovaikutustaidot, myönteisen ilmapiirin luominen, vastuun ja yhteisvastuun ymmärtäminen, konfliktien ratkaiseminen, yhdessä työskenteleminen, kumppanuuden rakentaminen ja verkostuminen. Myös erilaisuuden kunnioittaminen ja moninaisuuden arvostaminen, solidaarisuus ja luottamus katsotaan tärkeiksi.

Itsenäinen ja suunnitelmallinen toiminta täydentää sosiaalista vuorovaikutusta ja painottaa yksilöiden vaikutusmahdollisuuksia ja valtautumista oman opiskelun ja elämänpolitiikan suuntaamiseksi. Keskeistä on myös itseluottamuksen ja vastuuntunnon vahvistuminen niin opiskelussa, harrastuksissa, työssä kuin kansalaisenakin. Osataidoiksi ymmärretään mm. vahva itsetunto ja usko oppimismahdollisuuksiin ja oman elämän hallintaan ja ohjaamiseen valintojen ja ongelmien ratkaisun kautta. Keskeistä on tällöin myös ymmärtää historian kulkua ja yhteiskunnan toimintatapoja, jotta voi toimia sekä omien että muiden oikeuksien puolustamiseksi samoin kuin oikeudenmukaisen yhteiskunnan rakentamiseksi. (Rychen, 2003.)

Pelkistetysti avaintaitojen arviointikehys on esitetty oheisen kuvion tapaan (Gilomen, 2003, 184).

$\mathrm{E}$ dellä kuvattuina avaintaitoalueet ovat yleisiä, geneerisiä ja vuorovaikutteisia sekä sisältävät tietojen ja taitojen ohella asenteellisia ja arvostuksiin liittyviä aineksia. Arviointitarkoitukseen ne vaativat tarkempaa erittelyä ja määrittelyä. Olennaista on kuitenkin geneerisyys sekä tietojen, taitojen ja asenteiden yhdistäminen, tiedon pohtiva ja kriittinen käyttö autenttisissa elämäntilanteissa niin yksilön elämänlaadun kuin yhteiskunnan menestyksen ja sosiaalisen oikeudenmukaisuudenkin edistämiseksi. Arvioinnin tuloksena saadaan tietoa myös koulutustar- 
Ihmisoikeudet

Kestävä kehitys

Tasa-arvo

Tuottavuus

Sosiaalinen koheesio

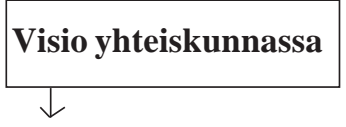

Teoreettinen pohdinta

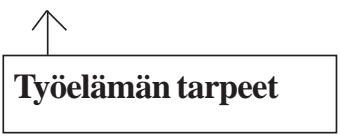

Teknologia

Monikulttuurisuus

Vastuullisuus

Globalisaatio

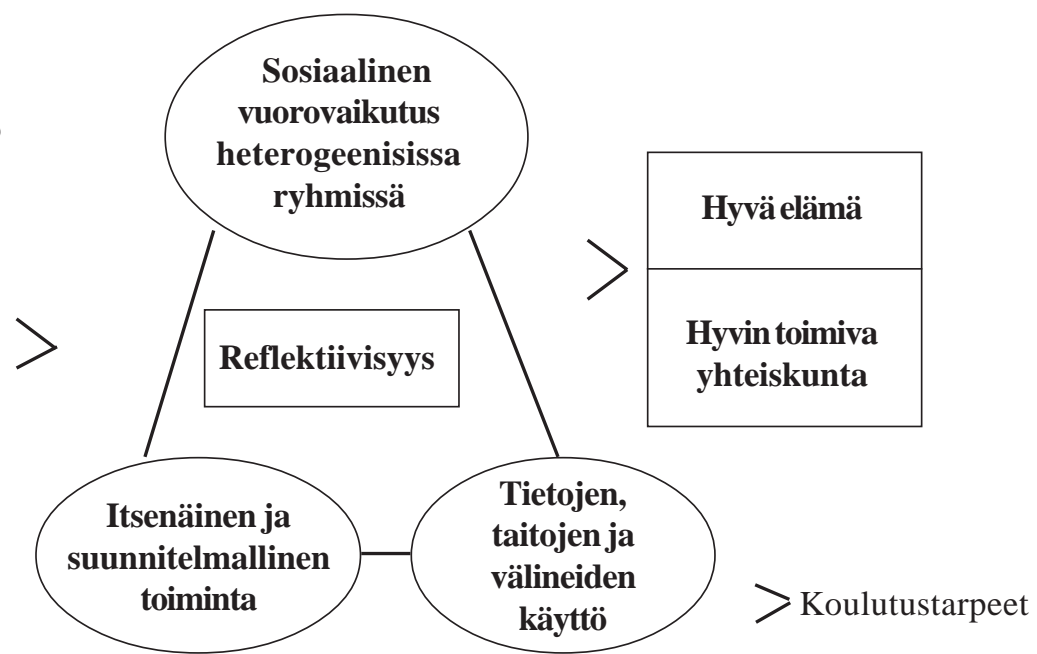

Aikuisten avaintaitojen arviointikehys (Gilomen, 2003, 184) peiden määrittelemiseksi ja koulutuksen kehittämiseksi.

\section{METODISIA HAASTEITA}

Aikuisten avaintaitojen kansainväliseen arviointiin liittyy monia metodologisia ongelmia, joita PIAACin yhteydessäkin on vielä ratkaistava. Päädytäänkö avaintaitojen arvioinnissa suoraan taitotestaukseen, mikä lisäisi osaamisen vertailtavuutta ja toisi työssä opitun paremmin esille, vai tyydytäänkö itsearviointiin, mikä saattaisi olla kansallisesti riittävä ja varmasti taloudellisesti edullisempi kuin taitotestaus, jossa mittavälineiden monikultuurinen ja -kielinen esitestaus ja validointi on sekä henkisiä että taloudellisia resursseja vaativa prosessi. Tämä liittyy osittain siihen, miten avaintaidot lopulta määritellään. Jos käytetään DeSeCo:n kehystä, laaja-alaiset taitoalueet on spesifioitava taitoalueita tarkemmin. Joillekin alueille on jo olemassa varsin luotettavia ja vertailukelpoisiakin mittareita, toisille niitä vasta kehitellään. Ensimmäisellä arviointikerralla itsearviointi voisi olla riittävä tai sitä kannattaisi käyttää taitotestauksen rinnalla kansainvälisen vertailtavuuden ja luotettavuuden varmistamiseksi.

Erityisen haasteen tarjoaa erilaisten työtehtävien vaatimusten arviointi, johon liittyy myös aiemman koulutuksen ja muiden oppimismahdollisuuksien kartoitus. Tehdäänkö arviointi työpai- kan, työntekijöiden vai työnjohdon näkökulmasta? Miten arvioidaan työttömiä ja työvoiman ulkopuolella olevia? Työtehtävien vaatimusten arviointiin on olemassa jo useita kansallisia malleja haastattelurungoista erilaisiin kyselylomakkeisiin, esimerkiksi Englannista ja Kanadasta. Miten nämä arviointivälineet toimivat muissa maissa? Työssä vaatimukset kohdistuvat myös tiimeihin tai verkostoihin, joita varten tulisi myös kehittää arviointivälineitä. Samoin avaintaitoihin tulisi sisällyttää niin yksilösuorituksia kuin yhteisöllisiäkin taitoja. Miten työ- ja koulutuskonteksti, yhteisöllisyys ja työkulttuuri kaiken kaikkiaan saadaan mukaan arviointiin, on vielä ratkaisematta.

Vilkasta keskustelua PIAACin suunnittelussa on herättänyt myös se, mihin ikäkohorttiin arviointi tulisi kohdistaa. Pyritäänkö kattamaan koko aikuisväestö vai rajataanko arviointi nuorimpiin aikuisiin, kaikkiin työikäisiin vai ikääntyviin? Useimmat Euroopan maat ovat eniten kiinnostuneita ikääntyvän väestön osaamisesta. Japani taas on ennen kaikkea huolissaan koulusta työelämään siirtyvistä nuorista aikuisista, jotka eivät enää olekaan kiinnostuneita yhtiöiden uraputkista eivätkä vanhempien tai työnantajien odotuksista, vaan haluavat kokea maailmaa ja vaihtoehtoisia elämäntapoja. Kaiken kaikkiaan PIAACin valmistelussa on useaan kertaan päädytty kysymään, mikä on yksilön kannalta ”hyvä elämä”, mikä yhteiskunnan näkökulmasta parhaiten toimivaa, yhteisöllistä ja tuottavaa. 
Vaikka uusissa EU:n ja OECD:n arviointiohjelmissa koulutuspoliittiset kysymykset ovat nousseet entistä keskeisimmiksi, arviointien teoreettiset ja metodiset vaatimukset ovat myös entisestään kasvaneet, mikä vahvistaa arviointien tutkimuksellista otetta. Arviointiohjelmia edeltää nykyisin vuosien kehittämistyö käsitteellisesti vahvojen kehysten rakentamiseksi sekä mittavälineiden laadinnan että tulosten tulkinnan, johtopäätösten teon ja hyödyntämisen pohjaksi. Niinpä PIAACin suunnittelu jatkuu vielä pari vuotta arviointikohteen tarkentamisella, mittavälineiden kehittämisellä ja esikokeiluilla osallistujamaissa, jotta varsinainen tiedonkeruu voidaan toteuttaa vuosina 2008-2009. Lopullinen arviointikehys julkistetaan myöhemmin kaikkien yleiseen keskusteluun ja kritiikkiin. Mittavälineet rakennetaan kehyksen pohjalta kansainvälisissä tutkimuskeskuksissa hyödyntäen sekä aiempien kansainvälisten että kansallisten arviointien mittavälineitä.

Arviointitutkimusten otannat suoritetaan keskitetysti kansallisten rekisteriaineistojen pohjalta siten, että alueellinen, etninen ja kielellinen edustavuus taataan. Jälkipainotuksilla korjataan otantaa ja vastaamattomuuden aiheuttamia vääristymiä. Katoanalyysit ovat tarkkoja ja puuttuvia havaintoja estimoidaan erilaisin kertoimin. Myös systeemisten selitys-, ennuste- ja seurausmallien rakentamiseen kehitetään jatkuvasti uudenlaisia tilastollisia menetelmiä, jotka ottavat huomioon aineistojen rakenteen. Monitasomallien hyödyntäminen tulosaineistojen analyysissa onkin tuonut merkittävää parannusta selitysmallien tarkentamiseen. Uudet graafiset ja visuaaliset esitysmuodot helpottavat tulosten tulkintaa ja johtopäätösten tekoa sekä monipuolistavat tiedottamista erilaisille yleisöille.

\section{EETTISIÄ EHTOJA}

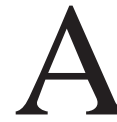

rviointiin liittyvät eettiset kysymykset, kuten arvioijan vastuullisuus ja arvioitavan kunnioitus, ansaitsevat entistä enemmän huomiota. Arvioinnin keskeisimpiä kysymyksiä onkin, miten arvioida oikein, hyvin ja arvokkaasti. Toisaalta arvioinnilta vaaditaan hyödyllisyyttä, vakuuttavuutta, vaikuttavuutta ja poliittista painoarvoa (Patton, 1997). Luotettavuus korvataan joskus uskottavuudella, riippumattomuus vuorovaikutuksen tärkeydellä.

Jaloimmillaan koulutuksen arviointi kuitenkin noudattaa ja edistää keskeisimpiä eettisiä arvoja, kuten totuudellisuutta, oikeudenmukaisuutta, tasa-arvoa, vastuullisuutta, rehellisyyttä ja suvaitsevuutta. Parhaimmillaan ja laajimmillaan arviointi tukee yhteiskunnassamme demokraattisesti sovittuja pyrkimyksiä tasa-arvoiseen koulutukseen ja tukee erityisesti niitä, joiden edellytykset ovat eri syistä muita heikoimmat. Arvioijan odotetaan tavoittelevan totuutta ja luotettavaa tietoa, jota hän hankkii tavoitteisiin sopivin ja pätevin menetelmin ottaen toiminnassaan huomioon arvioitavien edun, etenkin yksilön suojan. Arvioitavien etuihin kuuluu mm. se, että arvioinnin tarkoitus, keskeiset kriteerit ja seuraukset selvitetään avoimesti ennakkoon (Chelimsky, 1997).

Arvioinnin kulttuurinen, sosiaalinen ja poliittinenkin herkkyys on kuitenkin itsestään selvää, koska arviointi ei luonteensa mukaisesti ole intresseistä vapaata toimintaa, vaan asioiden arvottamista eli suhteuttamista sivistyksellisiin, sosiaalisiin ja taloudellisiin arvostuksiin. Vaikka arviointi on parhaimmillaan tutkimuksen luonteista ja noudattaa hyvän tutkimuksen kriteereitä, sen ensisijaisena tarkoituksena on toiminnan tai tuloksen arvon määrittäminen (Scriven, 1994). Arvioinnin tavoitteet ja kriteerit puolestaan suuntaavat sitä, mitä, miten ja millä seurauksilla arvioidaan.

Vaativimmillaan arviointi on soveltavaa tutkimusta, jolla on myös teoreettisesti kestävä arviointikehys, joka hyödyntää monipuolisesti ja tarkoituksenmukaisesti erilaisia lähestymistapoja ja metodologioita ja tuottaa tuloksia, jotka ratkaisevat koulutuksen todellisia ongelmia ja lisäävät ymmärrystä arviointikohteesta - olipa kyse aikuisten avaintaidoista, opiskelumotivaatiosta, koulutukseen hakeutumisen esteistä tai koko suomalaisen aikuiskoulutusjärjestelmän laadusta. Asiantunteva arvioija ymmärtää myös sen, että arvioinnit eivät perinteisessä mielessä ole tutkimusta, sillä ne eivät testaa teorioita eivätkä yksin riitä kausaalitulkintoihin. Pikemminkin ne auttavat rakentamaan hypoteeseja, joita jatkotutkimuksilla voidaan varmentaa.

Eettinen arvioija tuntee myös vastuunsa tulosten tulkinnasta. Hän ymmärtää tulosten historiallisen, kulttuurisen, taloudellisen ja sosiaalisen kontekstin merkityksen ja tekee johtopäätöksiä nämä huomioonottaen. Etenkin kansainvälisessä arvioinnissa taustakontekstin esilletuonti on tärkeää. Esimerkiksi UNESCOn arviointityössä Afrikan tai Etelä-Amerikan koulutusta on kohtuutonta verrata eurooppalaiseen, koska talou- 
delliset ja kulttuurisetkin resurssit ovat aivan toiset.

Arviointitutkija ei yleistä tuloksia, jos otanta ei riitä yleistyksiin ja ilmaisee selvästi tulosten luotettavuuden ja tulkinnan rajoitukset. Vastuullinen arvioija ei korosta eroja, jotka loppujen lopuksi ovat vähäisiä, vaikka suurissa aineistoissa olisivatkin tilastollisesti melkein merkitseviä; eikä toisaalta vähättele eroja, joita ilmenee esimerkiksi eri-ikäisten, eri sukupuolten, etnisten, kielellisten tai sosio-ekonomisten ryhmien välillä. Niinpä ammatillisesta aikuiskoulutuksesta syrjäytymisessä eivät alueitten väliset erot ole olleet merkittäviä, jos väestön ikärakenne ja koulutustausta otetaan huomioon. Toisaalta erot eri-ikäisten aikuisten välillä ovat todellisia, joita koulutustaustan erot vielä vahvistavat (Linnakylä \& Malin, 2002).

Oikeudenmukaista, pätevää ja eettisesti ihanteellista koulutuksen arviointi ei kuitenkaan ole aina. Ongelmalliseksi tilanteen tekee vielä se, etteivät eettiset arvostuksetkaan ole absoluuttisia vaan niiden välille syntyy käytännössä jännitteitä. Lisäksi eettiset periaatteet ovat käsitteellisesti monitulkintaisia, jopa ristiriitaisia (House, 1997). Esimerkiksi tasa-arvo voidaan ymmärtää koulutukseen pääsyn, resurssien, oppimismahdollisuuksien, valintojen tai pedagogisen ja sosiaalisen tuen tasa-arvona tai edellytyksiltään heikoimpien erilaisena kohteluna oikeudenmukaisuuden hengessä. Oikeudenmukaisuutta ei toisaalta voi olla ilman tasa-arvon oletusta (Rawls, 1971).

Totuudellisuuden ja avoimuuden arvostaminen voi puolestaan johtaa niin koulutuksellisiin ja sosiaalisiin uudistuksiin kuin arvioitavien oikeuksien loukkaamiseen ja heikkojen syrjimiseen. Tulisiko esimerkiksi tiettyjen maahanmuuttajaryhmien arviointituloksia julkistaa? Koulutusmahdollisuudethan ovat usein, etenkin naisilla, olleet aiemmin todella vähäiset. Oikeudenmukaisuuden ja reilun pelin hengessä tulosten julkistaminen on arveluttavaa. Toisaalta tulosten salailu ei ainakaan edistä näiden ryhmien opiskelumahdollisuuksien parantamista.

Koulutuksen kansainvälisissä arvioinneissa kulttuurisia, kielellisiä ja taloudellisia syrjintäepäilyjä herää jatkuvasti. Onko oikeudenmukaista vertailla tai arvioida täysin erilaisia ja eri tavoin resurssoituja koulutusjärjestelmiä ja niiden oppimistuloksia. Esimerkiksi IALS-arvioinnin yhteydessä eteläamerikkalaiset ja itäeurooppalaiset valittivat mittavälineiden suosivan länsieuroop- palaista ja angloamerikkalaista kulttuuria. Ranskalaiset, italialaiset ja espanjalaiset taas syyttivät englantia puhuvia maita kielellisestä ylivallasta. Meitä pohjoismaalaisia puolestaan huolestutti jatkuvasti se, ettei hyvinvointiyhteiskuntamme tasa-arvoajattelua painoteta tarpeeksi. Erilaisten kulttuuristen ja niihin liittyvien eettisten ristiriitojen pohtiminen ja tasapainottaminen käytännön arviointitilanteissa onkin kansainvälisen arvioinnin keskeisimpiä haasteita (House, 1997).

Eettisten ehtojen luonne ja tiukkuus liittyvät myös arviointiparadigmaan. Kun arvioinnin positivistinen, psykometrinen paradigma vaati ensisijaisesti tiedon ja arvojen erottelua, metodista vahvuutta, tiedon luotettavuutta ja pätevyyttä sekä tiedonkeruun riippumattomuutta, pragmaattiset opetussuunnitelma-, ohjelma- ja teema-arvioinnit taas painottavat arvioitavien osallistamista ja heidän arvostustensa huomioonottoa sekä arviointien hyödyllisyyden, tarkkuuden ja toteutettavuuden korostusta.

Konstruktivistinen oppijakeskeinen arviointi taas tähdentää voimakkaasti arvioitavien omia laatukriteereitä, oikeuksia ja etuja sekä korostaa arvioinnissakin pedagogista hyödyllisyyttä ja sovellettavuutta. Postmoderni arviointi on relativistista ja hyväksyy erilaiset näkemykset arvoista ja eettisistä periaatteista ja pyrkii pikemminkin murentamaan arvioinnin yhtenäistä arvoperustaa ja siihen perustuvaa asiantuntijuutta.

Arvioinnin monitahoisuus ja monimetodologisuus ja etenkin joidenkin arviointihankkeiden epätieteellisyys johtivat syystäkin 80 - ja 90-luvuilla arviointien tarpeellisuuden ja tieteellisyyden kyseenalaistamiseen. Etenkin uusliberalistinen tuloksellisuuden, tehokkuuden, taloudellisuuden ja markkinavoimien vaatiman hyödyn painottaminen on herättänyt kritiikkiä. Vastavoimaksi on vaadittu sosiaalisesti ja kulttuurisesti vastuullista arviointiparadigmaa. Etenkin Ernest House on korostanut eettisesti vastuullista arviointia, jossa arvioinnin periaatteita ja tuloksia pohditaan eettisestä näkökulmasta yhteisesti sovittujen arvojen kannalta ja tuodaan näkyväksi myös vallankäytön ja erilaisten intressiryhmien etuja. Eettisenä ihanteena on sosiaalinen oikeudenmukaisuus ja kansalaisvastuullisuus, jota edistetään kaikkien arviointitahojen tasa-arvoisella osallistamisella ja dialogisuudella, jossa valta-asetelmia avataan ja ristiriitoja ratkaistaan demokraattisesti neuvotellen (House, 1997; House \& Howe, 1999).

Jotta arviointi kehittäisi koulutusjärjestel- 
määmme ja -kulttuuriamme, se vaatii kaikkien osapuolten aktiivista osallistumista yhteiseen analyyttiseen, kriittiseen ja eettiseenkin keskusteluun niistä päämääristä ja kriteereistä, joita yhdessä pidämme arvokkaina. Sosiaalista vastuuta painottavan toiminnan sekä pätevän ja luotettavan tiedon avulla tietoyhteiskuntaa ja sen koulutusta voi kehittää yhteisesti toivomaamme suuntaan (Castells, 1998).

\section{LÄHTEET}

Castells, M. (1998). End of millenium. The information age: economy, society and culture. Vol. III. (Revised ed.) Oxford: Blackwell.

Chelimsky, E. (1997). The coming transformations in evaluation. In E. Chelimsky \& W. R. Shadish (Eds.) Evaluation for the 21st century. A handbook. Thousand Oaks: Sage, 126.

Collin, K. (2005). Experience and shared practice. Design Engineers' learning at work. University of Jyväskylä. Jyväskylä Studies in Education, Psychology and Social Research 261.

European Comission (2004). Implementation of "Education and Training 2010" Work Programme. Working Group B "Key Competences”. November 2004.

Gilomen, H. (2003). Desired outcomes: a successful life and well-functioning society. In D. Rychen, D. \& L. Salganik (Eds.) Key competencies for a successful life and a wellfunctioning society. Göttingen: Hogrefe \& Huber, 109-134.

Goody, J. (2001). Competencies and education: contexual diversity. In D. Rychen, D. \& L. Salganik. (Eds.) 2001. Defining and selecting key competencies. Bern: Hogrefe \& Huber, 175-190.

House, E. R. (1993). Professional evaluation. Social impact and political consequences. Newbury Park, CA: SAGE Publications.

House, E. R. (1997). Ethics of evaluation studies. In J.P. Keeves (Ed.) Educational research methodology, and measurement: an international handbook. $2^{\text {nd }}$ edition (pp. 257261). Cambridge University Press. Pergamon.

House, E. R. \& Howe, K. R. (1999). Values in evaluation and social research. Thousand
Oaks: Sage.

Howard, U. (2005). Adult literacy and education in UK. Keynote speech in Unesco conference on "Literacy in Europe", Lyon, the 4th of April, 2005.

Kuusi, O. (1996). Tulevaisuuden avaintaidot. Futura 4/96. Tulevaisuuden tutkimusseura ja Tampereen teknillinen korkeakoulu. Tampere.

Linnakylä, P., Malin, A., Blomqvist, I \& Sulkunen, S. (2000). Lukutaito työssä ja arjessa. Aikuisten kansainvälinen lukutaitotutkimus Suomessa. Jyväskylän yliopisto. Koulutuksen tutkimuslaitos.

Linnakylä, P. \& Malin, A. (2001). Demand for adult education and determinants of participation. In A, Tuijnman \& Z. Hellström (Eds.) Curious Minds. Nordic adult education compared. Nord 2001:9. Copenhagen: Nordic Council of Ministers, 68-103.

Linnakylä, P. \& Malin, A. (2002). Yli 40-vuotiaat aikuiskoulutuksessa: Aikuiskoulutukseen osallistuminen ja siitä syrjäytymien SIALSaineiston valossa. Teoksessa M.L. Stenström, P. Linnakylä, A. Malin, P. Nikkanen, E. Piesanen \& S. Valkonen, Yli 40-vuotiaat aikuiskoulutuksessa "Kyllä sieltä aina jotakin reppuun jää”. Helsinki: OPM, 171-236.

McNeil, B. (2005). Young adults, gender and literacy. Paper presented in Unesco conference in "Literacy in Europe", Lyon, the 3rd of April, 2005.

OECD 2000. Literacy in the information age. Final Report of the International Adult Literacy Survey. 2000. Paris/Ottawa: OECD \& Statistics Canada.

OECD 2001. Knowledge and skills for life. First results from PISA 2000. Paris: OECD.

OECD 2004. Meeting documents of the international expert group for the development of an OECD strategy for the Programme for the International Assessment of Adult Competencies (PIAAC). Paris: OECD, November 2004.

Patton, M. (1997) Utilization-focued evaluation. Thousand Oaks: Sage.

Pohjonen, P. (2005) Työssä oppiminen. Ammatillisen osaamisen perusta. PS-kustannus.

Ruohotie, P. (2005). Kvalifikaatioiden ja kompetenssien kehittäminen koulutuksen tavoit- 
teena. Teoksessa T. Varis (toim.) Uusrenesanssiajattelu, digitaalinen osaaminen ja monikulttuurisuuteen kasvaminen. Okkasäätiö, 31-49.

Rychen, D. (2003) Key competencies: meeting important challenges in life. In D. Rychen, D. \& L. Salganik (Eds.) Key competencies for a successful life and a well-functioning society. Göttingen: Hogrefe \& Huber, 63-108.

Rychen, D. \& Salganic, L. (2003) Introduction. In D. Rychen, D. \& L. Salganik (Eds.) Key competencies for a successful life and a well-functioning society. Göttingen: Hogrefe \& Huber, 1-12.

Rychen, D. \& Salganic, L. (2003). A holistic model of competence. In D. Rychen, D. \& L. Salganik (Eds.) Key competencies for a successful life and a well-functioning society. Göttingen: Hogrefe \& Huber, 41- 62.

Rychen, D. \& Salganik, L. (Eds.) 2001. Defining and selecting key competencies. Bern: Hogrefe \& Huber.

Rychen, D. \& Salganik, L. (2003). Key competencies for a successful life and a well-functioning society. Göttingen: Hogrefe \& Huber.
Salganic, L. \& Stephens, M. (2003). Competence priorities in policy and practice. In D. Rychen, D. \& L. Salganik (Eds.) Key competencies for a successful life and a well-functioning society. Göttingen: Hogrefe \& Huber, $13-40$.

Scriven, M. (1994).Evaluation as a discipline. Studies in Educational Evaluation 20, 1, 147-166.

Tynjälä, P. (2003). Ammatillinen asiantuntijuus ja sen kehittäminen tietoyhteiskunnassa. Teoksessa J. Kirjonen (toim.) Tietotyö ja ammattitaito. Jyväskylän yliopisto: Koulutuksen tutkimuslaitos, 39-62.

Vesterinen, M.-L. (2002). Ammatillinen harjoittelu osana asiantuntijuuden kehittymistä ammattikorkeakoulussa. Jyväskylän yliopisto. Jyväskylä Studies in Education, Psychology and Social Research 196.

Weinert, F. E. (2001). Concept of competence: a conceptual clarification. In D. Rychen, D. \& L. Salganik. (Eds.) 2001. Defining and selecting key competencies. Bern: Hogrefe \& Huber, 45-66.

Artikkeli saapui toimitukseen 5.7.2005. Se hyväksyttiin julkaistavaksi toimituskunnan kokouksessa 3.10.2005. 